\title{
ON THE ORIGIN AND GLACIAL TRANSPORT OF ERRATICS OF JOTNIAN SANDSTONE IN SOUTHWESTERN FINLAND
}

\author{
JOAKIM DONNER
}

DONNER, JOAKIM, 1996. On the origin and glacial transport of erratics of Jotnian sandstone in southwestern Finland. Bull. Geol. Soc. Finland 68, Part 2, 72-83.

Late Proterozoic Jotnian sandstone erratics were transported during the last Quaternary glaciation from the source area in Satakunta at the coast of southwestern Finland and the bottom of the Bothnian Sea to the southeast as far as Estonia, Latvia and Russia. The frequencies of the sandstone erratics show that they were transported greater distances than indicators of other rocks in the southern parts of Finland. In addition, high frequencies in small areas, south of Salo and in Bromarv, indicate that there are or were small separate source areas of Jotnian sandstone outside the main area. This is supported by the distribution of erratics of Cambrian sandstone and Ordovician sedimentary rocks in the same area. The tracing of possible small occurrences of Jotnian sandstone or Palaeozoic rocks is, however, difficult in an area with numerous faults and fracture zones in the Precambrian bedrock, where the depressions are covered by thick Quaternary drift.

Key words: erratics, facial transport, Jotnian, sandstone, stone counts, indicator fans, disperad, southwestern Finland

Joakim Donner, Department of Geology, P.O.Box 11, FIN-00014 University of Helsinki, Finland.

\section{INTRODUCTION}

During each Quaternary glaciation of Scandinavia erratics were transported by the ice away from the central parts of the area covered by the ice sheet towards its marginal parts. The directions of flow are best studied by using indicators of easily recognisable rocks with well known areas of origin, source areas, in the bedrock, combined with a study of the striae. When the studied erratics are from surface tills or from eskers and endmoraines in the area covered by ice during the Weichselian, they are from the Middle and Late Weichselian glaciation and it is thus the directions of ice flow from this time that are reflected in the shapes of the indicator 
fans. Outside this area, the directions of the transport of erratics were governed by the dynamics of the ice sheets of the older glaciations.

In using indicator fans their shapes have been compared with the known extents of the source areas. In some cases, however, the frequencies and distribution of the indicators have been used to show that the source area is more extensive than expected, as later supported by a more detailed mapping of the bedrock. In addition, irregularities in the frequencies of the indicators may be interpreted either as showing that there are source areas outside the main one, or that there are local irregularities in the distribution of erratics not conforming to the generally known regular pattern. Thus, if the source area of particular erratics are not known in detail they should by definition not be called indicators. The spread of erratics of Jotnian sandstone in southwestern Finland is an example of an irregular distribution with marked spatial fluctuations in the frequencies. In the present study a small area with high frequencies of erratics of Jotnian sandstone is compared with the occurrences of indicators within the broad fan of this sandstone as reconstructed in previous investigations.

The Precambrian, Late Proterozoic Jotnian sandstone is an unmetamorphic sedimentary cover of the Fennoscandian Shield, found in downfaulted blocks. It occurs in Satakunta in southwestern Finland in a graben downfaulted at least $650 \mathrm{~m}$ and also outside the coast at the bottom of the Gulf of Bothnia (Simonen, 1980). The Jotnian sedimentary rock consists in Satakunta of an orange-coloured to red stratified arkosic sandstone with current bedding and ripple marks related to a floodplain environment (Simonen, 1980, for details see maps by Hämäläinen, 1994, and Vorma and R. Niemelä, 1994). The Jotnian sandstone, which covers the older Precambrian igneous rocks, is particularly easy to recognise and is therefore most suitable for a study of erratics in the Quaternary glacial drift. The erratics of Jotnian sandstone can, furthermore, easily be separated from those of Cambrian sandstone also found in southwestern Finland (Uutela, 1989).

\section{PREVIOUS STUDIES}

Hausen (1912) summarised what was known about the spread of erratics of Jotnian sandstone at the beginning of the century in the areas surrounding the southern parts of the Baltic Sea. Fig. 1 is based on part of the map produced by Hausen (1912, Fig. 1) which also included eastern Sweden. The eastern lateral margin of the indicator fan shows how the erratics spread in a general southeasterly direction from southwestern Finland across the Baltic Sea into Estonia, Latvia and the western parts of Russia. Frequencies of $20-40 \%$ of Jotnian sandstone were found in the downstream direction of ice flow from the source area in southwestern Finland, and also on the Alland Islands. This led Hausen to conclude that the Jotnian sandstone also occurred in the bedrock at the bottom of the Bothnian Sea in the Gulf of Bothnia north of the Aland Islands (Fig. 1), a conclusion later verified when the bedrock of the sea floor was mapped in detail (Winterhalter et al., 1981). The lateral spread of erratics of Jotnian sandstone towards the eastsoutheast, as presented by Hausen (1912), was also reflected on the map of indicators found in glaciofluvial sediments of eskers and endmoraines in southwestern Finland, particularly in the sediments of the Salpausselkä I moraine as far east as Hyvinkää (Donner, 1986), from where Hausen (1912) had already recorded sandstone indicators.

Fig. 2 shows the frequency in southwestern Finland of pebbles and cobbles, based on 341 stone counts and earlier published data, as presented by Salonen (1991, Fig. 1), but leaving out the Åland Islands included in his original map. The frequency of Jotnian sandstone erratics is $60-90 \%$ in the till in the source area on land (see also Uutela, 1989) and $20-40 \%$ in the downstream direction of ice flow almost as far as to the Salpausselkä III endmoraine. Beyond this moraine the frequencies drop below $10 \%$, being in the area between Salpausselkä I and Salpausselkä III 1-5\%. As the source area is comparatively large, the dispersal of Jotnian sandstone erratics represents, according to Salonen (1991), a case of long-distance transport 


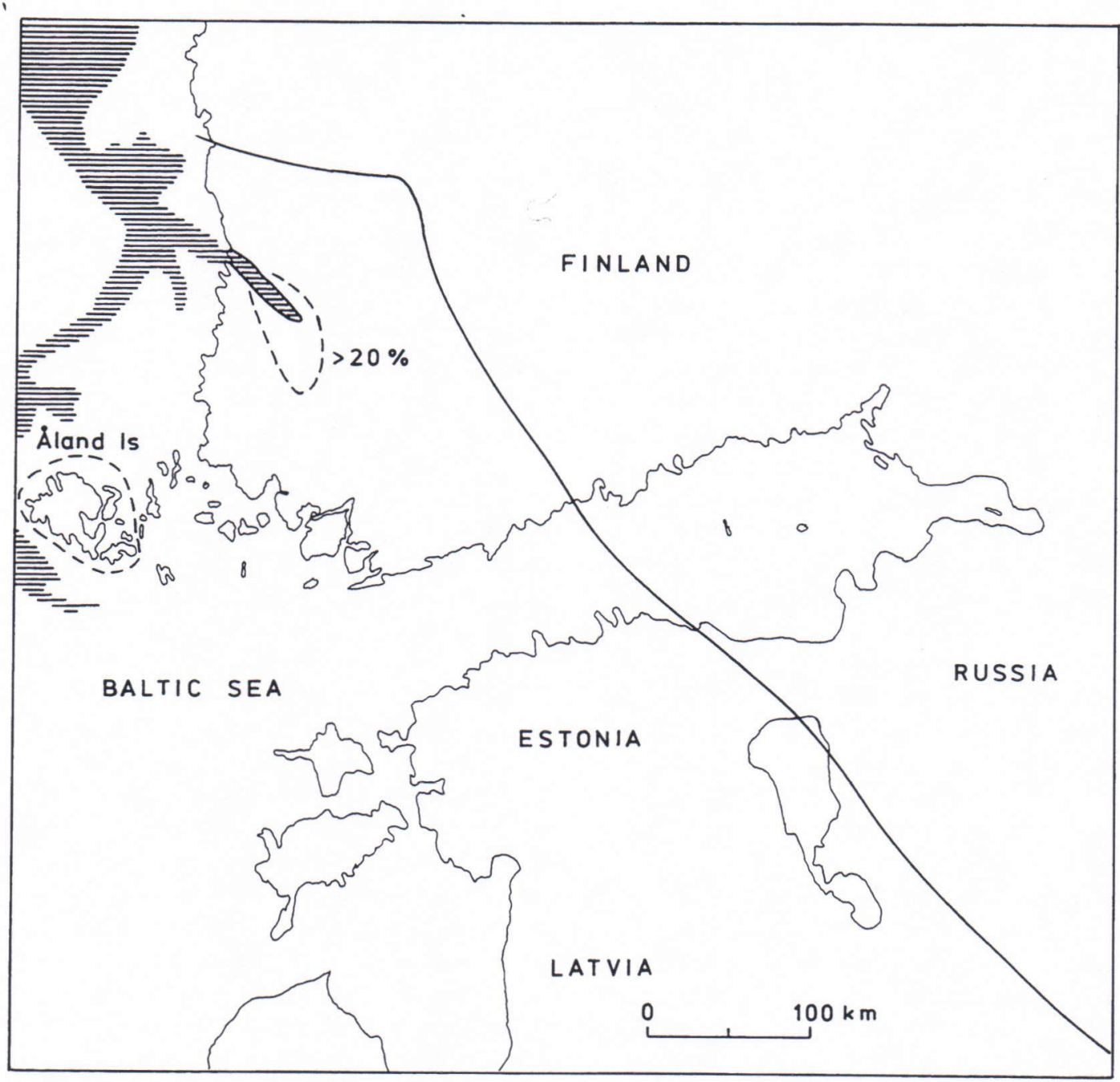

Figure 1. Eastern lateral margin of indicator fan for Jotnian sandstone with its source area in Satakunta, southwestern Finland, with areas of erratic frequencies over $20 \%$ (20-40\%), after map by Hausen (1912). The source area on land is after Hausen and the area outside the coast, based on later studies, after Winterhalter et al. (1981).

but with a flow pattern showing also a late movement towards east-southeast during the deglaciation. The general pattern of the spread of the erratics of Jotnian sandstone in both till and glaciofluvial material can, according to Salonen, be explained by a transport from the known source area on the mainland and on the sea floor west of the Finnish coast. The existence of small unknown source areas of Jotnian sandstone with high local frequencies of erratics is not, according to Salonen, impossible but has not been verified, such as by drilling through the Quaternary sediments into the underlying bedrock.

Of the areas suggested as having possible hidden local occurrences of Jotnian sandstone in the bedrock, that of Vammala (Matisto, 1964) is south- 
east of Pori and southwest of Tampere, about 40 $\mathrm{km}$ east of the source area of sandstone in Satakunta (Fig. 2). It is in the area where the frequencies of erratics have been affected by a late ice movement towards the east. The proportion of sandstone in the glaciofluvial esker material reached $5 \%$ in some stone counts. In 144 stone counts along the Säkylä-Mellilä esker northwest of Salo the sandstone frequencies were $80-90 \%$ in the glaciofluvial material of the esker and 30-40 $\%$ in the till close to the distal edge of the source area of the Jotnian sandstone of Satakunta (Kaitanen and Ström, 1978). After a decrease in the direction of ice flow the frequencies again rose to $10-20 \%$ in the esker material and up to $50 \%$ in the surrounding till $20-30 \mathrm{~km}$ from the distal edge of the area of Jotnian sandstone. Taking into account the spatial variations in the frequencies of sandstone erratics northwest of Salpausselkä III, as reflected in Fig. 2, and dispersal scattergrams presented by Salonen (1991) along three traverses, the results from the two above-mentioned areas, Vammala and Säkylä-Mellilä, do not necessarily show that there are unknown areas of Jotnian sandstone outside the area in Satakunta shown in Fig. 2.

In contrast to the two areas mentioned above, the sandstone erratics found in a $2 \mathrm{~km}^{2}$ large area in the zone of Salpausselkä III consisting of small parallel ridges, south-southeast of Salo (Leskelä and J. Niemelä, 1972), may have come from a source area closer than that of the Jotnian sandstone $80 \mathrm{~km}$ away in Satakunta (Fig. 2). The average frequency of sandstone erratics larger than 20 $\mathrm{cm}$ in six stone counts was $25.8 \%$, in two of them over $30 \%$. In addition several big angular boulders of about $2 \mathrm{~m}^{3}$ were found. Additional stone counts in the Salo area gave similar results (Niemelä et al., 1987). It was assumed that the source area for the sandstone erratics is in some nearby depression, hidden under Quaternary sediments; in the Salo area the clays alone reach a thickness of 100 m (Leskelä and J. Niemelä, 1972).

Viewed against the general dispersal of Jotnian sandstone erratics in southwestern Finland (Fig. 2) there is, as suggested above, an indication of a local source area in the bedrock near Salo, but no conclusive evidence for its presence. Another area with high frequencies of sandstone erratics is the Bromarv-Tenala (Tenhola) area further south, from where Uutela (1989) reported high frequencies of Jotnian sandstone erratics in presenting her stone counts from southwestern Finland. Additional stone counts made later in the Bromarv area (for its position see Fig. 2) also showed that it has a relatively high concentration of erratics of Jotnian sandstone and in this respect differs from surrounding areas. As the results from the Bromarv area have a bearing on the interpretation of the dispersal of Jotnian sandstone erratics in southwestern Finland in general they were included in the present account.

\section{THE BROMARV AREA}

Salpausselkä II forms a distinct endmoraine ridge following the shore east-northeast of Bromarv, but southwest of Bromarv it becomes a wider more even formation of glaciofluvial material (Fig. 3). The bedrock is dissected by several fracture zones and faults, as reflected in the direction of the narrow bays on each side of the endmoraine. In the middle of the area shown in Fig. 3, at Framnäs where Salpausselkä II forms a narrow isthmus, the frequencies of Jotnian sandstone erratics are noticeably high as compared with the surrounding areas nearby. 20 stone counts of $10-20 \mathrm{~cm}$ big pebbles and cobbles were made at sites along the Salpausselkä II endmoraine as well as from a few sites on each side of the moraine. The percentages of sandstone were in 10 stone counts, in which the frequencies were high, based on 300-800 stones and in the remaining 10 counts on $100-200$ stones. Large angular boulders, some of them flat, but with a diameter of at least $1 \mathrm{~m}$, were mapped separately (Fig. 3). Some of the boulders, as also many of the flat stones, had well preserved ripples without any signs of wear (Fig. 4 ), and on the whole all the erratics are angular.

The results from the stone counts show that the highest frequencies of Jotnian sandstone erratics were found at Framnäs, where also big boulders were found, in addition to those found south and 


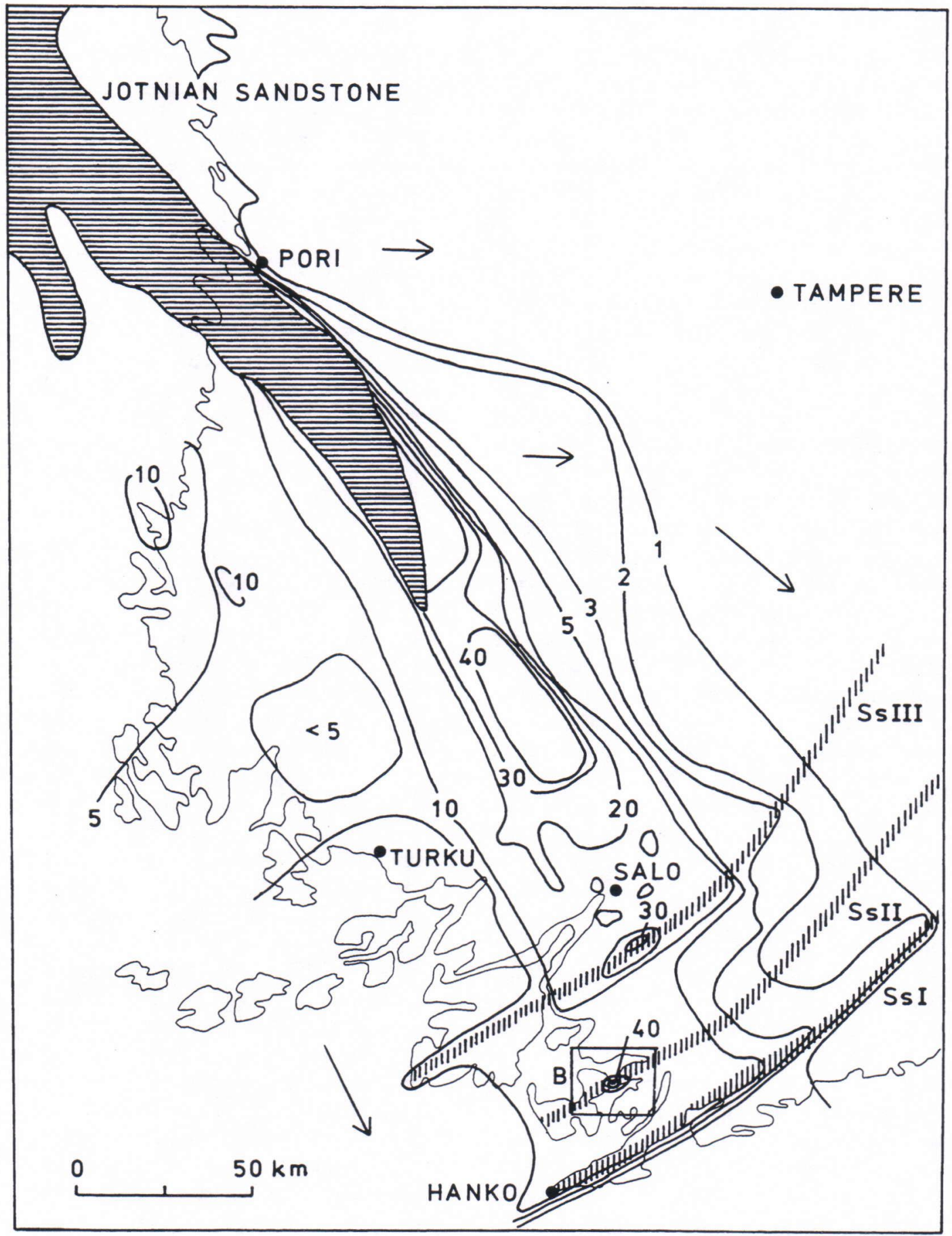

Figure 2. Dispersal of Jotnian sandstone pebbles and cobbles in southwestern Finland, giving the frequencies in percentages (after Salonen, 1991). Arrows show the direction of ice movement during deglaciation. Ss I-Ss III, Salpausselkä moraines; B, area in Bromarv shown in Fig. 3 (added to map by Salonen). 


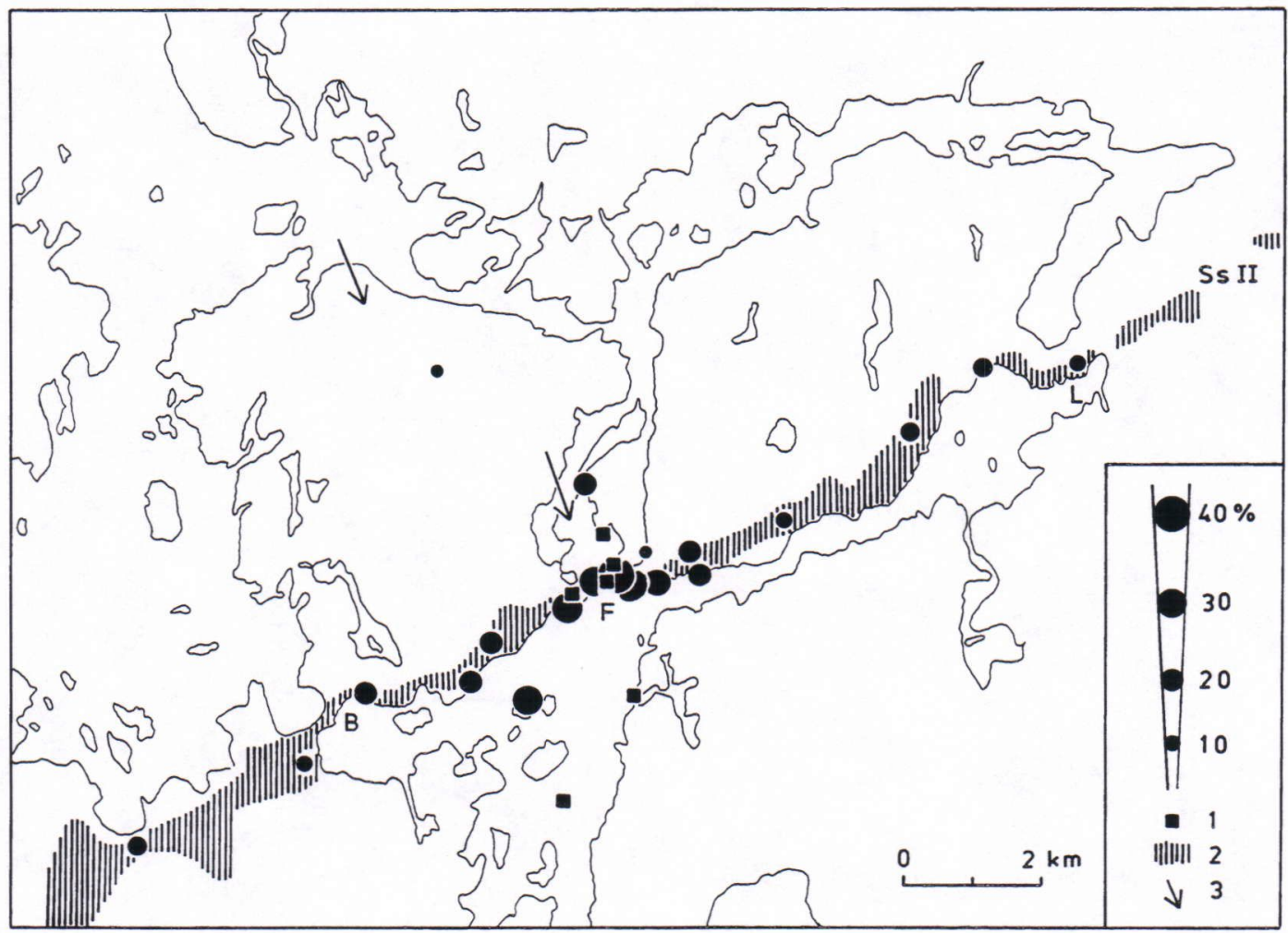

Figure 3. The Bromarv area showing the frequencies of Jotnian sandstone erratics $(10-20 \mathrm{~cm}$ big pebbles and cobbles) in the glaciofluvial sediments of Salpausselkä II (Ss II) and in the surrounding till. 1, large angular boulder; 2, Salpausselkä II; 3, main direction of ice movement, based on measurements of striae. B, Bromarv; F, Framnäs; L, Lindö.

north of Framnäs (Fig. 3). The percentages of sandstone erratics along Salpausselkä II from the southwest to the northeast were $13,10,19,19$, $18.5,27,27,41,37,26,21,21,11,16,13,12$, those underlined being from Framnäs. The frequencies of sandstone were $32 \%$ at the site south of Salpausselkä II and $6 \%, 18 \%$ and $4 \%$ at the three sites north of the endmoraine. It can thus be seen that whereas the frequency of sandstone reaches $41 \%$ at Framnäs the frequencies elsewhere along the moraine are 10-19\%. Compared with surrounding areas with frequencies between $5 \%$ and $10 \%$ (Fig. 2) the Bromarv area as a whole has a high proportion of Jotnian sandstone erratics, not only in glaciofluvial material of the Salpausselkä II moraine but also in the till close to this ridge.
The area investigated in Bromarv lies about 100 $\mathrm{km}$ from the distal edge of the Jotnian sandstone area in Satakunta south of Pori (Fig. 2) and about $160 \mathrm{~km}$ from the area of sandstone at the bottom of the Bothnian Sea north of the Alland Islands, as pointed out by Uutela (1989). As the general direction of ice movement in the Bromarv area was from north-northwest the source area for the sandstone erratics should be located in that direction. As there is no known exposed or hidden occurrence of Jotnian sandstone between the area south of Pori and the Bromarv area a discussion of the likelihood of the presence of unknown source areas of Jotnian sandstone in southwestern Finland has to be based on comparisons with results from 


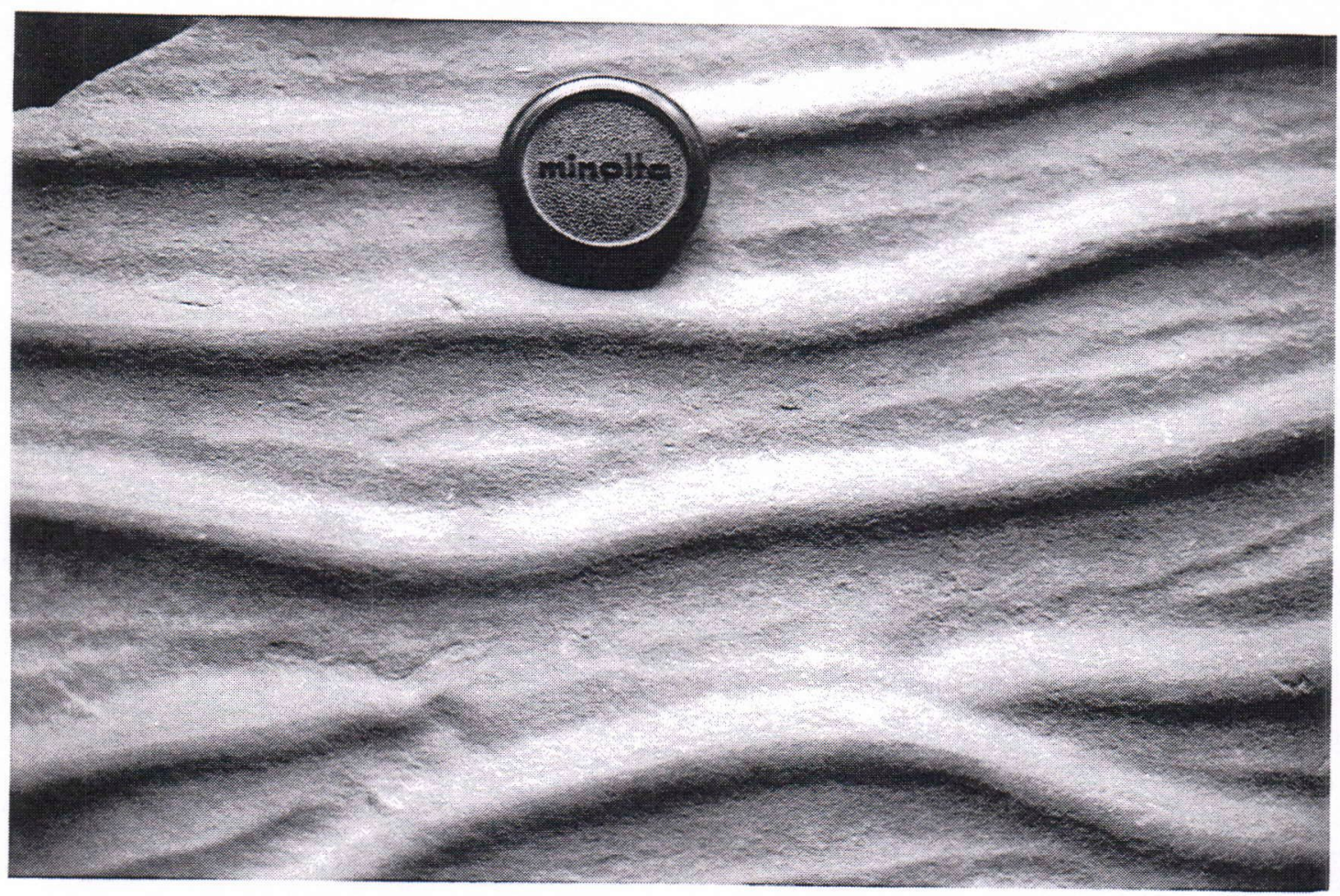

Figure 4. Surface of $7 \times 55 \times 105 \mathrm{~cm}$ big boulder with ripples from Framnäs, Bromarv (Geological Museum, University of Helsinki).

studies of the dispersal of erratics in general in this area, and also in other areas.

\section{CONCLUSIONS}

The map in Fig. 2 reflects the irregularities in the frequencies of Jotnian sandstone erratics in southwestern Finland. The same irregularities are seen in Fig. 5 showing the scatter of Jotnian sandstone percentages from stone counts along a traverse southeastwards from the known source area at the coast south of Pori, as presented by Salonen (1991, Traverse 3 in Figs 2 and 3), with the results from the Bromarv area added. The curve indicates the maximum frequencies along a $200 \mathrm{~km}$ long traverse. Because of the narrow shape of the source area of Jotnian sandstone in its distal part the frequencies show a dip in this area, as also seen in Fig. 2. After a decrease in the frequencies at about $100 \mathrm{~km}$ there are two peaks, the first at Salpausselkä III near Salo and the second at Salpausselkä II in Bromarv. Both peaks are, as seen in Fig. 2, restricted to relatively small areas and do not reflect an increase laterally along the endmoraines. At the Salpausselkä I moraine no area with high frequencies has been recorded.

In discussing the pattern of the dispersal of Jotnian sandstone erratics in southwestern Finland Salonen (1991), as mentioned, concluded that it can be "explained solely by known transport mechanisms from known provenance areas in the Gulf of Bothnia and Satakunta basins", but he also pointed out that the dispersal "represents a rare case of a long-distance transport system". The significance of this statement can best be elucidated by making a comparison between the spread of 

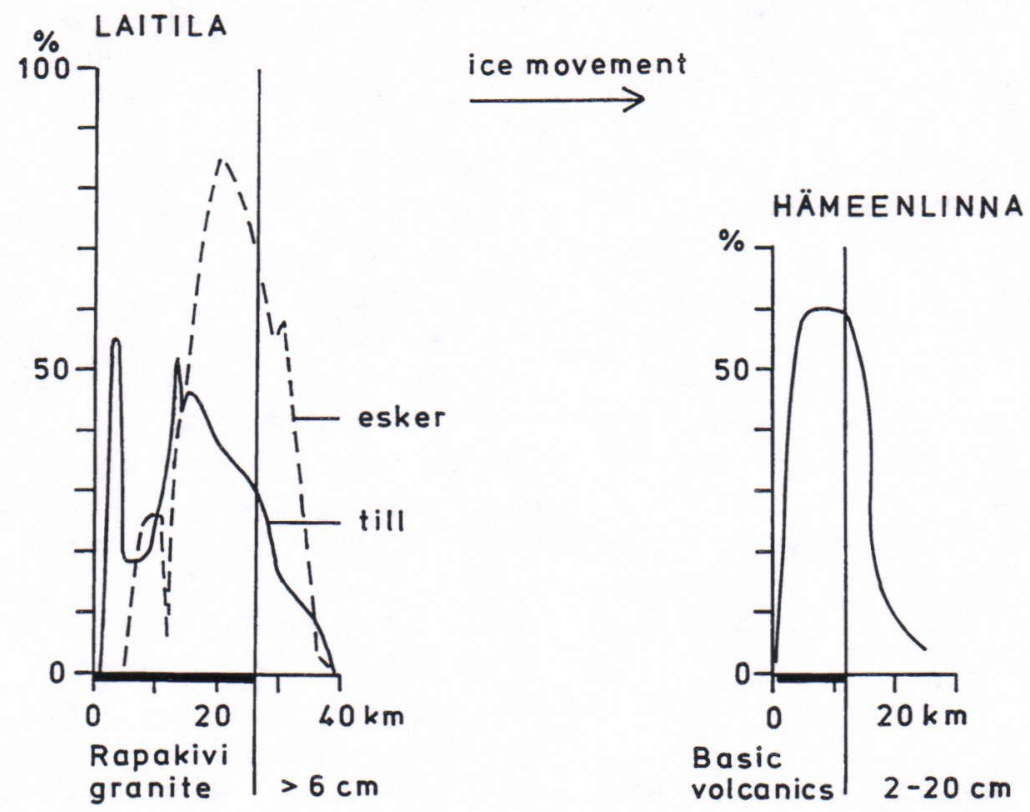

$\%$ SOUTHWESTERN FINLAND

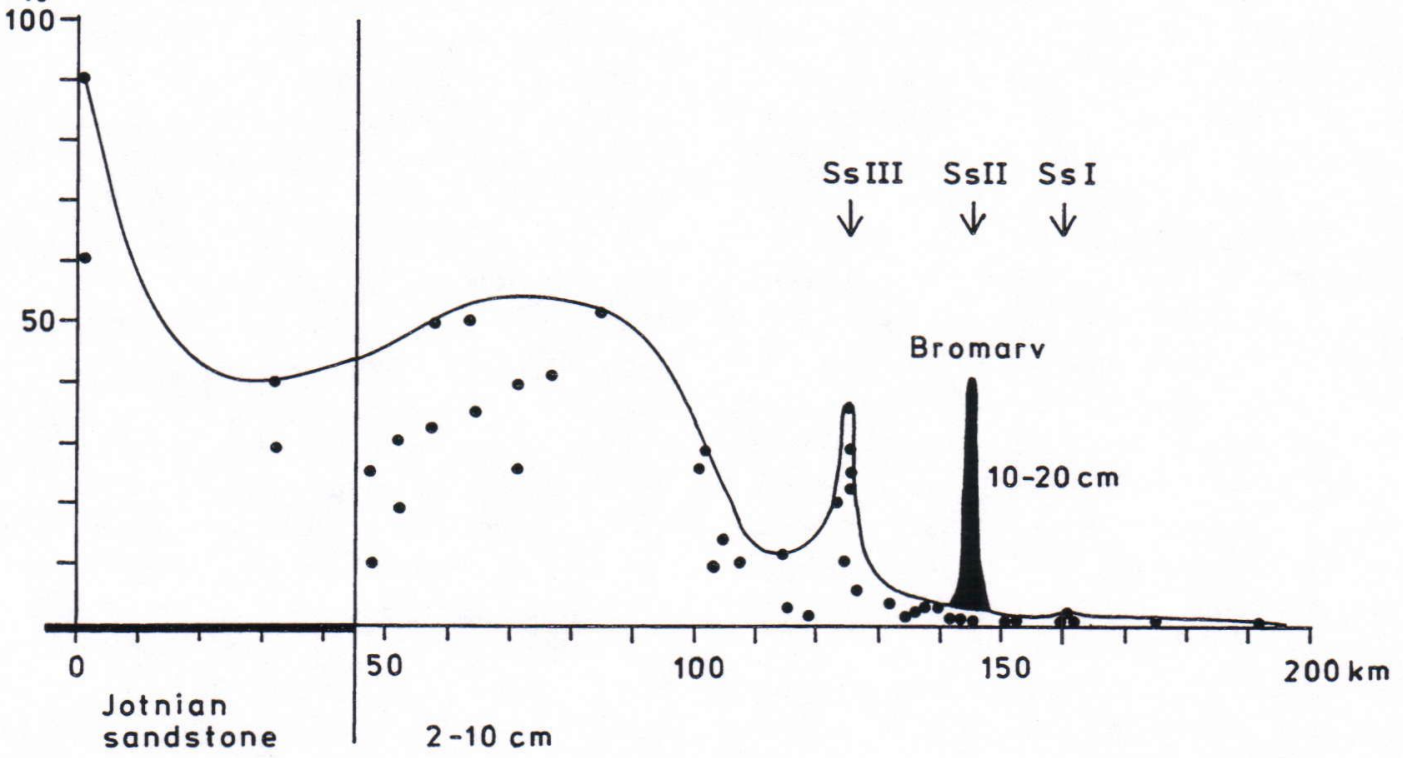

Figure 5. The lower curve shows the scatter of Jotnian sandstone percentages along a traverse southeastwards from the source area in Satakunta (Salonen 1991, Traverse 3 in Figs 2 and 3), with the results from the Bromarv area added. The upper curves show the frequencies of rapakivi granite in Laitila in the esker and in till (after Hellaakoski, 1930) and the frequencies of basic volcanics in Hämeenlinna (Perttunen, 1977). 
Jotnian sandstone erratics in the direction of ice movement and of other erratics, particularly of indicators with source areas in southern Finland where the glacial history is similar to that in $\mathrm{Sa}$ takunta at the west coast. Even if there were a number of factors that influenced the transport distances of erratics, the observed decrease of the relative amount of the indicators in the direction of ice movement, after the distal contact of the source area, has generally been found to be so regular that exponential curves can be used to show the decrease. The curves have been presented as straight lines in diagrams to a semilogarithmic scale. Further, in describing the transport distances of particular indicators half-distance values have been quoted, which give the distances at which the frequencies have been halved, by Perttunen (1977) defined as the distances from the distal contact of the source area.

The most suitable area for comparison with the distribution of the Jotnian sandstone erratics is the rapakivi granite massif at the west coast of Finland, immediately south of the area of Jotnian sandstone. Here Hellaakoski (1930) studied erratics both in glaciofluvial material in the Laitila esker and in the surrounding till, along a transect in the direction of ice movement across the rapakivi area where it is nearly $27 \mathrm{~km}$ wide. The frequencies along this transect of clasts bigger than $6 \mathrm{~cm}$ are shown in Fig. 5. In the rapakivi area the frequencies of erratics are nearly twice as high in the esker material as in the till. The frequencies in the till rise steeply $1.5 \mathrm{~km}$ from the proximal contact and fall to below $20 \% 1-3.5 \mathrm{~km}$ after the distal contact. In the glaciofluvial material of the esker there is an increase up to 80-90\% 5-8 km after the proximal contact and a sharp fall $5-8 \mathrm{~km}$ after the distal contact. The distance of 5-8 km has been held to be an average distance for esker material in Finland (Lilliesköld, 1990). The second example for comparison given in Fig. 5 is from the Hämeenlinna area of the transport of erratics of the $2-20 \mathrm{~cm}$ fraction of basic volcanic rocks in till from an source area about $11 \mathrm{~km}$ wide (Perttunen, 1977, Fig. 7 II). Here, as in the Laitila area (Hellaakoski, 1930), the indicators were transported a relatively short distance, even if the frequencies rose to about
$60 \%$ in the source area. The half-distance values determined by Perttunen (1977) for the basic volcanic rocks from two traverses were $4.2 \mathrm{~km}$ and $5.6 \mathrm{~km}$.

The conclusions drawn from the two examples given in Fig. 5 are in agreement with those in the more extensive study of the glacial transport of boulders in Finland by Salonen (1986) and in his summary of studied boulder fans (Salonen, 1987). In the former study, in which all rock types represented in the boulder counts were taken into account, the average transport distances determined varied between $0.4 \mathrm{~km}$ and $17.0 \mathrm{~km}$ in the cover moraine and drumlin areas. According to the summary of 464 boulder fans (Salonen, 1987) they are normally $1-5 \mathrm{~km}$ long with a median length of 3.0 $\mathrm{km}$. The transport distances of erratics in eskers have generally shown the same pattern as in the study by Hellaakoski (1930) in the Laitila esker, as, for instance, in the study by Virkkala (1958) of the Hämeenlinna esker. Less than $40 \%$ of the erratics were transported more than $5 \mathrm{~km}$.

The comparison of the dispersal of Jotnian sandstone erratics in southwestern Finland with the dispersal of indicators in the same or neighbouring areas show, in agreement with the conclusion by Salonen (1991), that the transport distances for the sandstone from the Satakunta area are unusually great (Fig. 5). The two relatively small areas with high frequencies of sandstone erratics south of Salo at Salpausselkä III and in Bromarv at Salpausselkä II cannot, however, be explained as a result of a known tranport mechanism encountered elsewhere. The high frequencies are not only restricted to the glaciofluvial material of the endmoraine ridges, but occur also in the surrounding till. Furthermore, the erratics, including the large boulders, are noticeably angular and without any signs of wear, as earlier pointed out. No equivalent high frequencies of sandstone have been recorded from the Salpausselkä I moraine. In the numerous studies of the transport of indicators the decrease in the frequencies has, as mentioned, been shown to be rather regular, even if the half-distance values have varied. It is therefore most likely that the erratics in the area south of Salo and in Bromarv came from separate small local source areas, away 
from the known main area of Jotnian sandstone in Satakunta and the bottom of the Bothnian Sea. These small source areas, if they exist and are not totally eroded, most likely occur in some small protected downfaulted areas or fracture zones covered by thick Quaternary sediments and therefore not detected, somewhere northwest of the areas in which the high sandstone frequencies have been found. The likely distances to the possible source areas for the Jotnian sandstone erratics south of Salo and in Bromarv cannot, however, easily be determined because of the observed great variations in glacial transport distances. In addition, less is known about the origin of the material in the endmoraine ridges of the Salpausselkäs than of the glaciofluvial material of eskers and of till. There are neither south of Salo nor in Bromarv feeding eskers joining the endmoraine ridges and thus no direct connection with the glaciofluvial transport of esker material and the accumulation of the moraine ridges.

The conclusion about possible small local occurrences of Jotnian sandstone outside the known area in Satakunta is in keeping with the observations of erratics of Cambrian quartz sandstone. The largest known occurrence of Cambrian or possibly Eocambrian (Tynni and Hokkanen, 1982) sandstone on land in Finland is on the Lauhanvuori hill in southern Ostrobothnia, about $100 \mathrm{~km}$ north of the Jotnian sandstone area in Satakunta. Because of the sandstone being resistant to erosion it remains as a hill at $230 \mathrm{~m}$ a.s.l. and is clearly above its surroundings. The frequencies of the sandstone boulders vary on top of the $12 \mathrm{~km}$ wide source area between $31 \%$ and $92 \%$, then decrease in the direction of ice flow to below $20 \% 3 \mathrm{~km}$ from the distal contact and below $10 \% 12 \mathrm{~km}$ from the contact (Simonen and Kouvo, 1955). The decrease of erratics is similar to those found in Laitila and Hämeenlinna shown in Fig. 5, and clearly different from the dispersal pattern of Jotnian sandstone erratics. In addition to the Lauhanvuori occurrence, Cambrian sandstone has been recorded as fillings of cavities in the Precambrian crystalline limestone or in veins in southwestern Finland (Simonen and Kouvo, 1955). Further, erratics have been recorded throughout this area (Uutela, 1989). The greatest frequencies, up to $10 \%$, are at the west coast, closest to the Cambrian sediments at the bottom of the Bothnian Sea north of the Ålands Islands. Elswhere the frequencies are 1-2\%, on the mainland usually below $1 \%$ according to the stone counts recorded by Uutela (1989). There are, however, some areas with slightly higher frequencies, one being Bromarv with $5 \%$. In the archipelago southwest of Bromarv, west of Hanko (Fig. 2), Edelman (1951) found frequencies of up to $20 \%$ and large boulders up to $1 \mathrm{~m}$ thick and $2 \mathrm{~m}$ across, of Cambrian sandstone as well as Jotnian sandstone on some islands and concluded that they originate from a local source in a depression below the present water-level. The above-mentioned examples show that it is likely that there are or were small preserved occurrences in southwestern Finland of Jotnian sandstone, as in Salo and Bromarv, in some places together with Cambrian sandstone, as west of Hanko and probably also in Bromarv, from which erratics were locally dispersed. The distribution and possible local origin of these erratics, as well as of Ordovician erratics also encountered in southwestern Finland, were discussed in detail already by Uutela (1989) in her study of a large number of erratics of especially Palaeozoic sedimentary rocks.

It was assumed in the discussion above that there are or were small separate areas in southwestern Finland with Jotnian sandstone and/or Cambrian and possibly Ordovician sedimentary rocks. Another possible explanation for high local frequencies of erratics of these rocks, at least in some instances, should be mentioned. There is an at least theoretical possibility that the high frequencies were caused by vast erratics having been carried intact by ice, and which later were broken and crushed into smaller clasts (Sugden and John, 1976). Large angular megablocks of quartzite, showing no glacial striae, are known to have been transported at least $300 \mathrm{~km}$ in Alberta in Canada (Prest and Nielsen, 1978). Little, however, is known about the mechanics of the transport of large blocks and if and how they possibly disintegrated into smaller fragments before deposition. It is therefore not possible to judge if some of the concentrations of erratics in southwestern Finland 
were caused by the transport of exceptionally large blocks of rocks. If such a transport did take place there would be no need for the assumption that there is a local source area in each place where there are high frequencies of erratics of a particular rock. Whether sandstones and sedimentary rocks in general are more susceptible than igneous rocks to being broken and transported as large blocks is not known.

ACKNOWLEDGEMENTS: The author is most grateful for the invaluable help he received from the late Professor K. O. Donner and his family in doing several stone counts and in tracing sandstone boulders in Bromarv 1982-94. He also wants to thank Dr. Jouko Nuorteva for his study in 1986 and 1988 of the sediments and bedrock in the narrow bays in Bromarv, particularly north of Framnäs, with the help of echosounding and acoustic reflection profiles, and Dr. Jouko Niemelä for arranging in 1990 the Geological Survey of Finland to study a $600 \mathrm{~m}$ long seismic profile immediately north of Salpausselkä II at Kägra west of Framnäs, and in 1991 to drill three boreholes down to the bedrock along this profile. As none of these attempts at tracing possible local occurrences of sandstone gave positive results the reports of them were not included in the present account. Finally, the author is grateful to Dr. Anneli Uutela for her comments on the manuscript. 


\section{REFERENCES}

Donner, J. 1986. Weichselian indicator erratics in the Hyvinkää area, southern Finland. Annales Academiae Scientiarum Fennicae A III 140, 20 pp.

Edelman, N. 1951. Glacial abrasion and ice movement in the area of Rosala-Nötö, S. W. Finland. Bulletin de la Commission géologique 154, 157-169.

Hämäläinen, A. 1994. Geological map of Finland, pre-Quaternary rocks, sheet-1134-Kokemäki. Geological Survey of Finland.

Hausen, H. 1912. Data beträffande frekvensen af jotniska sandstensblock i de mellanbaltiska trakternas istidsaflagringar. Geologiska Föreningens i Stockholm Förhandlingar 34, 495-499.

Hellaakoski, A. 1930. On the transportation of materials in the esker of Laitila. Fennia 52 (7), $42 \mathrm{pp}$.

Kaitanen, V. and Ström, O. 1978. Shape development of sandstone cobbles associated with the SäkyläMellilä esker, southwest Finland. Fennia 155, 23 67.

Leskelä, S. and Niemelä, J. 1972. Hiekkakivilohkareita III Salpausselällä Salon kaakkoispuolella. Geologi 1972 (5-6), 58-60.

Lilliesköld, M. 1990. Lithology and transport distance of glaciofluvial material. In: Glacial inticator tracing, eds R. Kujansuu and M. Saarnisto, 151-164. Rotterdam: Balkema.

Matisto, A. 1964. Onko Tyrvään Vaunujoella hiekkakiveä. Geologi 1964 (10), 153-154.

Niemelä, J. (ed.), Stén, C-G., Taka, M. and Winterhalter, B. 1987. Turun-Salon seudun maaperä. Geological map of Finland 1: 100000 , Explanation to the maps of Quaternary deposits, Sheets 1043 and 2021, Geological Survey of Finland, $83 \mathrm{pp}$.

Perttunen, M. 1977. The lithologic relation between till and bedrock in the region of Hämeenlinna, southern Finland. Geological Survey of Finland, Bulletin 291, $68 \mathrm{pp}$.

Prest, V. K. and Nielsen, E. 1987. The Laurentine ice sheet and long-distance transport. Geological Survey of Finland, Special Paper 3, 91-101.

Salonen, V-P. 1986. Glacial transport distance distributions of surface boulders in Finland. Geological Survey of Finland, Bulletin 338, 57 pp.

Salonen, V-P. 1987. Observations on boulder transport in Finland. Geological Survey of Finland, Special Paper 3, 103-110.

Salonen, V-P. 1991. Glacial dispercal of Jotnian sandstone fragments in southwestern Finland. Geological Survey of Finland, Special Paper 12, 127-130.

Simonen, A. 1980. The Precambrian in Finland. Geological Survey of Finland, Bulletin 304, 58 pp.

Simonen, A. and Kouvo, O. 1955. Sandstones in Finland. Bulletin de la Commission géologique $168,57-87$.

Sugden, D. E. and John, B. S. 1976. Glaciers and landscape. London: Edward Arnold, 376 pp.

Tynni, R. and Hokkanen, K. 1982. Annelidien ryömimisjälkiä Lauhanvuoren hiekkakivessä. Geologi 1982 (7), 129-134.

Uutela, A. 1989. Age and dispersal of sedimentary erratics on the coast of southwestern Finland. Geological Survey of Finland, Bulletin 349, 100 pp.

Virkkala, K. 1958. Stone counts in the esker of Hämeenlinna, southern Finland. Bulletin de la Commission géologique 180, 87-103.

Vorma, A. and Niemelä, R. 1994. Geological map of Finland, pre-Quaternary rocks, sheet-1133-Yläne. Geological Survey of Finland.

Winterhalter, B., Flodén, T., Ignatius, H., Axberg, S. and Niemistö, L. 1981. Geology of the Baltic Sea. In The Baltic Sea, ed. A. Voipio, 1-121. Amsterdam: Elsevier Oceanography Series 30 . 